\title{
Anthropometric and dietetic evaluation of people with ileostomies
}

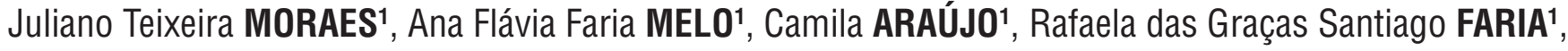 \\ Nize Renê FERREIRA² and Vinícius Silva BELO'
}

Received 8/10/2018 Accepted 18/2/2019

\begin{abstract}
Background - The maintenance of nutrition for the person with ileostomy is a major challenge despite to the proper management of stoma eliminations. Objective - This study aimed to evaluate the nutritional status of people with ileostomy. Method - This is a cross-sectional study carried out on a population of 17 people with ileostomy enrolled in the Service of Attention to the Health of the Person with Stoma of level II, referring to a health region in Minas Gerais. The anthropometric evaluation consisted of the collection of weight, height, and calculation of body mass index. A 24-hour food recall and the nutritional assessment method Global Subjective Assessment were also evaluated. The data were analyzed by the Dietbox software, where the ingested nutrients were estimated, and by the Statistical Package for the Social Sciences version 22.0. Results - There was a predominance of a population composed of people over 50 years old, female, married and single, with family income between two and three minimum wages, incomplete elementary school and that did not exercise paid activity. The cancer was given as the main diagnosis that originated the stoma and had a surgery time of less than two years. Regarding nutritional status, most of the interviewees presented adequate body mass index, but more than half reported significant weight loss after the ileostomy. The predominant nutritional diagnosis provided by the General Subjective Assessment was "suspected malnutrition/moderate malnutrition". On the other hand, the contribution of energy, carbohydrates, lipids, sodium, potassium, magnesium and vitamin B12 was considered insufficient in almost all the participants. Conclusion - Therefore, it is suggested the periodic evaluation of the nutritional status of this population. Thus, it is expected that preventive, therapeutic and maintenance dietary diagnosis and planning may contribute to the nutritional status of the person with the ileostomy.
\end{abstract}

HEADINGS - Nutritional status. Ostomy. Health services.

\section{INTRODUCTION}

The intestinal stoma is an anastomosis between a segment of the intestine and the skin of the anterior abdominal wall. Such a derivation may be performed from a portion of the large intestine, that is a colostomy, or from the distal small intestine, and is then called ileostomy. Its creation may be necessary in the management of a variety of pathological conditions, such as congenital anomalies, inflammatory bowel diseases, obstructions, trauma or neoplasms ${ }^{(1)}$.

With the exteriorization of the small intestine, the absorption of water, minerals, and nutrients is compromised, which exposes people with ileostomy to dehydration, electrolytic disturbances and impaired nutritional status ${ }^{(2)}$. Besides to lipids, carbohydrates, and proteins, the ileum is also responsible for the absorption of vitamin $\mathrm{B} 12$. The large intestine is responsible for the absorption of water and electrolytes, such as sodium, potassium, and magnesium ${ }^{(3)}$. The nutritional needs of people with ileostomy vary based on the extent and absorption capacity of the remaining bowel, general health, major diagnosis and comorbidities of the individual ${ }^{(4)}$.

Failure to fully absorb essential nutrients can result in a malnourished person with compromised quality of life. Therefore, a balanced diet is necessary, considering the type, the occasion, and the frequency the foods are offered, to minimize the losses and the liquidity effects of the products excreted. Intensive replenishments of liquid, proteins, salts and others should be performed to provide enough nutrients ${ }^{(5,6)}$.

In addition to reduced absorption capacity due to intestinal resection, people with ileostomy begin to adopt eating habits to control intestinal functions for aesthetic reasons, such as avoiding odor, flatulence, and bulky content. These changes in diet may have negative repercussions, contributing to a worsening of the nutritional status of these subjects, especially when the diet is not adjusted for their needs ${ }^{(5)}$.

Given that adequate management of stoma eliminations and maintenance of nutrition for the person with ileostomy are two major challenges, and that these individuals are more predisposed to develop malnutrition ${ }^{(4)}$, follow-up is necessary for the evaluation of eating habits and anthropometric data. Thus, it is possible to provide subsidies for the development and implantation of nutritional plans, estimating if food intake is sufficient and identifying inappropriate habits, such as excessive intake of foods with poor nutritional content ${ }^{(7)}$.

The nutritional status of an individual is a result of the relationship between food consumption and nutritional needs, and its evaluation allows the identification of people at risk, contributing to the promotion or recovery of health. It is necessary to use an

Declared conflict of interest of all authors: none

Disclosure of funding: no funding received

Research performed at: Serviço de Atenção à Saúde da Pessoa Ostomizada de nível II (SASPO II). Secretaria Municipal de Saúde de Divinópolis, MG, Brasil.

${ }^{1}$ Universidade Federal de São João Del-Rei, Campus Centro-Oeste Dona Lindu, Divinópolis, MG, Brasil. ${ }^{2}$ Secretaria Municipal de Saúde de Divinópolis, MG, Brasil.

Corresponding author: Juliano Teixeira Moraes. E-mail: julianotmoraes@ufsj.edu.br 
association of several indicators of nutritional status to increase diagnostic accuracy, such as analysis of clinical and dietary history and anthropometric data. Thus, it is possible to establish the nutritional diagnosis, being the basis for dietary planning and guidance ${ }^{(7)}$.

Therefore, this study aimed to evaluate the nutritional status of individuals with ileostomy enrolled in a referral service for health care of the person with stoma.

\section{METHODS}

This is a descriptive cross-sectional study conducted with people with ileostomy enrolled in a Level II Stoma Care Service (SASPO II), a reference for a health region in Minas Gerais. It is a service with a multidisciplinary team consisting of a doctor, a nurse, a social worker, a psychologist, and a nutritionist. It provides specialized and interdisciplinary assistance to people with a stoma, aiming at their rehabilitation, including guidance for self-care, prevention, and treatment of complications in the stomas, training, supply of collecting equipment and adjuvants of protection and safety ${ }^{(8)}$.

SASPO II is a reference for a region with a population estimated at 433,163 inhabitants, of whom 200 have stomas and are enrolled in the service, and 20 of them have ileostomy. People with ileostomy registered up to December 2016, with a minimum age of 18 years old, of both genders and with preservation of their psychic functions were considered eligible. Those who were hospitalized at the time of data collection were excluded. All of them met the inclusion criteria and were invited to participate in the survey. Thus, the total population corresponded to 20 individuals.

The project was approved by the Research Ethics Committee through opinion number $1,077,361$. The participation in the research involved the signing of a free and informed consent form. Data collection was performed from August to December 2016 through an interview.

An anthropometric evaluation was performed, which consisted of the participants' weight, height, and body mass index (BMI) calculation; a 24-hour food recall; and the nutritional assessment method Global Subjective Assessment (ASG). Also, participants answered a questionnaire about their sociodemographic and clinical information.

BMI is recommended as a nutritional diagnosis method for adults and the elderly people by the Food and Nutrition Surveillance System - SISVAN ${ }^{(9)}$. It is calculated by dividing the weight of the individual $(\mathrm{kg})$ by the square of its height $\left(\mathrm{m}^{2}\right)$, with distinct classifications for adults and the elderly people. According to the value obtained, the adult can be classified as underweight, adequate weight, overweight and obese, and, in the case of the elderly person, underweight, adequate weight and overweight ${ }^{(10)}$. It has the advantages of being able to obtain weight and height measurements, as well as a high correlation with body mass and body composition indicators ${ }^{(9)}$.

The 24-hour food recall evaluates the current diet and it can estimate data on energy and nutrient intake in the total food intake by the individual. Its advantage is its rapid application and short recall period. As a limitation of this type of dietary assessment, there is a need for the interviewee's memory for qualitative and quantitative information about meals and, above all, the biggest limitation is that a single day of recall may not represent the usual intake of an individual ${ }^{(7)}$.
ASG is a validated instrument for assessing nutritional status, based on clinical history and physical examination data. Changes in usual weight, changes in eating habits, presence of gastrointestinal symptoms, disturbances in functional capacity and metabolic demand of the main diagnosis of the individual are investigated through anamnesis. Also, it is submitted to a simple physical examination, which evaluates changes in muscle and subcutaneous composition, and the presence of edema. Thus, at the end of the evaluation, the individual is then classified subjectively in category 1 (nourished), 2 (suspected of malnutrition or moderately malnourished) or 3 (severe malnutrition) ${ }^{(11)}$. This method has become popular in the evaluation of the nutritional condition and the simplicity and the good correlation with anthropometric and biochemical parameters are some advantages. However, the main criticism of this instrument lies in the fact that accuracy depends on the experience of the observer ${ }^{(12)}$.

The Dietbox software was used for the estimation of the nutrients ingested, from the food recall, and for the evaluation of the sufficiency of each of them. Ingested amounts of energy, carbohydrates, lipids, proteins, sodium, potassium, magnesium and vitamin B12 were evaluated.

All data were entered into the Statistical Package for the Social Sciences (SPSS) software version 22.0 for processing and analysis. Descriptive statistics were performed.

\section{RESULTS}

The sample (n) consisted of 17 participants, excluding those who were not available to attend the data collection on the scheduled dates. The mean age of the interviewees was 55.8 years old and the median age 55 years old, being the minimum age 26 and maximum 80 years old. Among them, $11(64.7 \%)$ were female and $6(35.3 \%)$ were male. Most of the individuals were single $(35.3 \%)$ or married $(35.3 \%)$.

The level of education with the highest prevalence was incomplete elementary education, being pointed out by $13(76.5 \%)$ participants. Complete primary education $(11.8 \%)$ and complete secondary education $(11.8 \%)$ were the other options indicated. The most mentioned family income was the value between two and three minimum wages, reported by eight participants $(47.1 \%)$.

Regarding the exercise of remunerated activity, $58.8 \%$ of the participants are unemployed or retired, and this same percentage does not practice physical activity. It was also investigated whether these individuals present other comorbidities, reported by $41.2 \%$ of them. Diabetes mellitus had the highest prevalence, present in $23.5 \%$ of the total participants, followed by systemic arterial hypertension (17.6\%). TABLE 1 shows the sociodemographic and health data of the study participants.

Regarding the capacity for self-care, $52.9 \%$ of the individuals reported being fit, $23.5 \%$ partially dependent and $23.5 \%$ totally dependent to perform the necessary care with the stoma. The present or previous presence of complications related to the stoma was pointed out by most of the participants $(82.4 \%)$, with dermatitis being the most frequent complication $(76.5 \%)$. As a cause for the creation of ileostomy, neoplasia was the main responsible, cited by seven people $(41.2 \%)$, followed by inflammatory disease $(23.5 \%)$. The mean duration of ileostomy from the date of surgery to the day of the interview was three years and three months, with a minimum time of one and a half months and a maximum time of 15 years. TABLE 2 presents the data of the participants, regarding the stoma. 
TABLE 1. Sociodemographic and health characteristics of people with ileostomy of the SASPO level II micro-region, Divinópolis 2016.

\begin{tabular}{|c|c|c|}
\hline Variables & $\mathrm{n}$ & $\%$ \\
\hline \multicolumn{3}{|l|}{ Age } \\
\hline$<40$ years old & 2 & 11.8 \\
\hline 40 to 50 years old & 3 & 17.6 \\
\hline 50 to 60 years old & 6 & 35.3 \\
\hline$>60$ years old & 6 & 35.3 \\
\hline \multicolumn{3}{|l|}{ Gender } \\
\hline Female & 11 & 64.7 \\
\hline Male & 6 & 35.3 \\
\hline \multicolumn{3}{|l|}{ Marital status } \\
\hline Single & 6 & 35.3 \\
\hline Married & 6 & 35.3 \\
\hline Stable union & 2 & 11.8 \\
\hline Widow & 2 & 11.8 \\
\hline Other & 1 & 5.9 \\
\hline \multicolumn{3}{|l|}{ Education level } \\
\hline Incomplete elementary school & 13 & 76.5 \\
\hline Complete elementary school & 2 & 11.8 \\
\hline Complete high school & 2 & 11.8 \\
\hline \multicolumn{3}{|l|}{ Family income } \\
\hline$<1$ minimum wage & 1 & 5.9 \\
\hline 1 to $<2$ minimum wages & 7 & 41.2 \\
\hline 2 to $<3$ minimum wages & 8 & 47.1 \\
\hline 4 or more minimum wages & 1 & 5.9 \\
\hline \multicolumn{3}{|l|}{ Profession } \\
\hline Active & 7 & 41.2 \\
\hline Inactive & 10 & 58.8 \\
\hline \multicolumn{3}{|l|}{ Practice physical activity } \\
\hline Yes & 7 & 41.2 \\
\hline No & 10 & 58.8 \\
\hline \multicolumn{3}{|l|}{ Comorbidities } \\
\hline Diabetes & 4 & 23.5 \\
\hline Arterial hypertension & 3 & 17.6 \\
\hline Others & 4 & 23.5 \\
\hline
\end{tabular}

Source: SASPO level II of Divinópolis - MG.

The analysis of the anthropometric data showed that 10 participants found normal weight for height and age (58.8\%), one was classified as low weight (5.9\%), four were overweight $(23.5 \%)$ and two individuals were classified as grade I obesity (11.8\%). Also, subjects were asked about their usual weight and current weight. Of them, $64.7 \%$ reported that their current weight is less than their usual weight, before the preparation of the ileostomy. The mean weight loss percentage presented was $17.07 \%$.

The nutritional assessment provided by the ASG classified eight participants as suspected malnutrition/malnourished moderates $(47.1 \%)$ and two as malnourished (11.8\%). The rest of the participants are nourished $(41.2 \%)$. In the last six months, weight loss was reported by nine individuals (52.9\%). Regarding the change in eating habits, seven participants reported alteration after surgery, and, regarding functional capacity, 10 reported having some type of dysfunction. Data on BMI and ASG can be seen in TABLE 3.
TABLE 2. Characteristics related to ileostomy and clinical data of people with ileostomy of the microorganism of the SASPO level II, Divinópolis 2016.

\begin{tabular}{lcc}
\hline Variables & $\mathbf{n}$ & $\%$ \\
\hline Assessment of the possibility of self-care & & \\
Able & 9 & 52.9 \\
Partially dependent & 4 & 23.5 \\
Totally dependent & 4 & 23.5 \\
Presence of complications & & \\
Yes & 14 & 82.4 \\
No & 3 & 17.6 \\
Type of complications & & \\
Retraction & 1 & 5.9 \\
Prolapse & 2 & 11.8 \\
Dermatitis & 13 & 76.5 \\
Others & 4 & 23.5 \\
Time of surgery & & \\
$\quad$ 2 years & 12 & 70.6 \\
2 to 5 years & 2 & 11.8 \\
> 5 years & 3 & 17.6 \\
Cause of the stoma & & \\
Cancer & 7 & 41.2 \\
Trauma & 1 & 5.9 \\
Inflammatory disease & 4 & 23.5 \\
Others & 5 & 29.4 \\
\hline
\end{tabular}

Source: SASPO level II of Divinópolis - MG.

TABLE 3. Anthropometric data and referring to the global subjective evaluation of people with ileostomy of the SASPO II microregion, Divinópolis 2016.

\begin{tabular}{lcc}
\hline Variables & $\mathrm{n}$ & $\%$ \\
\hline BMI & 1 & 5.9 \\
$\quad$ Low weight & 10 & 58.8 \\
Normal weight & 4 & 23.5 \\
Overweight & 2 & 11.8 \\
Obesity - Grade I & & \\
Lost weight in recent weeks & 9 & 52.9 \\
Yes & 8 & 47.1 \\
$\quad$ No & & \\
Food intake compared to usual & 10 & 58.8 \\
$\quad$ Without changes & 7 & 41.2 \\
$\quad$ With changes & & \\
Functional capacity & 7 & 41.2 \\
$\quad$ No dysfunction & 10 & 58.8 \\
$\quad$ With dysfunction & & \\
Subjective evaluation & & \\
$\quad$ Nourished & & 47.1 \\
Suspected malnutrition & & 41.2 \\
Severe malnutrition & 2 & 11.8 \\
\hline
\end{tabular}

Source: SASPO level II of Divinópolis - MG. 
Regarding the estimation and evaluation of nutrient sufficiency, most of the respondents presented an inadequate consumption of energy $(58.8 \%)$, carbohydrates $(58.8 \%)$ and lipids $(88.2 \%)$. The protein intake was adequate in most participants $(76.5 \%)$. As for micronutrients, most of the individuals consumes an adequate amount of sodium $(5.9 \%)$, as well as potassium $(5.9 \%)$, magnesium $(17.6 \%)$ and vitamin B12 (11.8\%). It was found that six interviewees $(35.3 \%)$ use dietary supplements in their diet. TABLE 4 shows data on the sufficiency of energy and ingested nutrients.

TABLE 4. Data related to the ingestion of nutrients obtained by 24 hour food recall of people with ileostomy of the microorganism of the SASPO II, Divinópolis 2016.

\begin{tabular}{|c|c|c|}
\hline Variables & $\mathrm{n}$ & $\%$ \\
\hline \multicolumn{3}{|l|}{ Energy consumed } \\
\hline Enough & 7 & 41.2 \\
\hline Not enough & 10 & 58.8 \\
\hline \multicolumn{3}{|l|}{ Protein intake } \\
\hline Enough & 13 & 76.5 \\
\hline Not enough & 4 & 23.5 \\
\hline \multicolumn{3}{|l|}{ Carbohydrate intake } \\
\hline Enough & 5 & 29.4 \\
\hline Not enough & 12 & 70.6 \\
\hline \multicolumn{3}{|l|}{ Lipid intake } \\
\hline Enough & 2 & 11.8 \\
\hline Not enough & 15 & 88.2 \\
\hline \multicolumn{3}{|l|}{ Sodium intake } \\
\hline Adequate & 1 & 5.9 \\
\hline Little Inadequate & 2 & 11.8 \\
\hline Enough & 14 & 82.4 \\
\hline \multicolumn{3}{|l|}{ Potassium intake } \\
\hline Adequate & 1 & 5.9 \\
\hline Inadequate & 16 & 94.1 \\
\hline \multicolumn{3}{|l|}{ Magnesium intake } \\
\hline Adequate & 3 & 17.6 \\
\hline Little Inadequate & 1 & 5.9 \\
\hline Inadequate & 13 & 76.5 \\
\hline \multicolumn{3}{|l|}{ Vitamin B12 intake } \\
\hline Adequate & 2 & 11.8 \\
\hline Little inadequate & 4 & 23.5 \\
\hline Inadequate & 11 & 64.7 \\
\hline \multicolumn{3}{|l|}{ Use of supplement } \\
\hline Yes & 6 & 35.3 \\
\hline No & 11 & 64.7 \\
\hline
\end{tabular}

Source: SASPO level II of Divinópolis - MG.

\section{DISCUSSION}

The reduced size of the population shows the results in studies with stomas, in which there is a markedly lower percentage of individuals with ileostomy when compared to colostomies ${ }^{(5)}$. Also, there is a greater number of studies with restricted attention to colonic stomas, which may be justified by the fact that an ileostomy is less frequent ${ }^{(6)}$. However, this finding evidences the need for further studies and a attention to these individuals, including due to the higher rate of complications found in this type of stoma and the difficulties in its management ${ }^{(2,3)}$.

In this population, the number of people over 50 years old was predominant. The fact that the oncological diagnosis also prevails in this group justifies the predominant age group. There is a greater agreement between neoplasms and stomas aged over 40 years old, with an exponential increase in incidence as the age advances, so that aging is a risk factor for the development of neoplasia and consequently the possibility of performing a stoma ${ }^{(13)}$.

Regarding the gender of the interviewees, the female was predominant. However, when compared to studies that were performed with participants with stomas, most were male ${ }^{(14-21)}$. The disagreement among the most prevalent gender surveys may be due to the close incidence of colorectal neoplasia among men and women, with an estimated risk of 16.84 new cases per 100,000 men and 17.10 per 100,000 women, according to the National Cancer Institute (INCA) ${ }^{(22)}$.

As for marital status, most were married and single, both with a frequency of $35.3 \%$. In other studies ${ }^{(14-18,21,23,24)}$, the prevailing civil status was married, ranging from $35.6 \%$ to $71.4 \%$. Marital status is a relevant factor, from a psychosocial point of view, due to the support and adaptation that people with ileostomy need, in which the spouse can play a fundamental role, improving the quality of life of these individuals ${ }^{(2)}$.

The predominant level of education among the participants was incomplete primary education. This factor should be valued, since a lower level of education is related to a higher rate of complications with the stoma, poor adherence to the treatment and, therefore, a higher risk of morbidity. Thus, it is essential to identify them by health professionals, who must implement educational self-care actions, to overcome the learning limitations that these individuals may present ${ }^{(23)}$.

The high rate of low education can be explained by the high prevalence of older people who, due to the social conditions of their time, had fewer opportunities for study ${ }^{(14)}$. Also, this data may be related to wage income, which is another characteristic evaluated by many studies, in which most have a low-income predominance ${ }^{(15,16,18,23,24)}$. Low income may also imply the deterioration of care with the stoma, since this demand specialized care, such as food, devices, consultations, among others, which are not always adequately provided by SUS ${ }^{(23,24)}$.

Regarding the exercise of paid activity, $58.8 \%$ of respondents are inactive. The fact that most of the population is composed of elderly people, who retired for the time of contribution and/or the benefit of the disability classified retirement, in which individuals with a stoma are inserted, is associated to this situation. However, the physical, psychic and social factors related to the presence of the stoma should not be ignored, since social reinsertion becomes a great challenge. These subjects feel incapacitated to develop previously performed activities, lack of privacy to maintain care with the stoma, because they feel more fragile and limited to perform certain functions or because they prefer not to expose themselves ${ }^{(14-16,23)}$.

Only $41.2 \%$ of the participants reported practicing physical activity regularly. The practice of physical activity is not common in the population with stomas ${ }^{(26)}$. Although not the experience of this group, the Brazilian Association of People with Stoma guides the practice of exercises, using the innumerable benefits related to health as a whole, positively influencing self-esteem, mental capacity, cholesterol, depression, chronic diseases, among others. 
Therefore, it is important to emphasize the encouragement, by health professionals, to the practice of physical exercises ${ }^{(27)}$.

The time elapsed between the surgery and the interview ranged from one month and a half to 15 years, while in other studies, this interval was shorter, from seven months to eight years ${ }^{(15)}$ and from one month to two years ${ }^{(21)}$. However, in a study carried out in Maceió, with 216 individuals with a stoma ${ }^{(28)}$, the maximum time was 20 years and minimum was less than one year, in which most had 0 to 5 years of stoma.

Regarding to the management with the stoma, $52.9 \%$ of the participants declared to be self-sufficient. It is known that factors such as marital status, higher levels of education and family income can influence self-care, since they increase the individual's confidence and self-esteem, contributing to empower the individual about his condition and care ${ }^{(23)}$.

When evaluating the complications involving the stoma, it was verified that the peristomal dermatitis had a higher incidence. The appearance of complications is directly related to factors such as type of surgery, in which the ileostomy is more prone to develop dermatitis due to its more liquid content; characteristics of the stoma (shape, protrusion, location); care given to the stoma, as well as variables such as education level, income and the presence of relatives ${ }^{(16,29)}$.

Although participants had adequate BMI, weight loss after ileostomy was recorded in $64.7 \%$ of the interviewees. This result is similar to studies evidencing a higher prevalence of adequate BMI among individuals with ileostomy, but with high rates of weight loss and nutritional depletion according to other nutritional parameters $^{(30,31)}$. The group with ileostomy tends to have a lower BMI when compared to the control group ${ }^{(2)}$.

No studies were found in the literature using ASG in subjects with stomas. In this study, most of the participants (47.1\%) were classified as suspected malnutrition/moderate malnutrition according to this instrument, and two participants $(11.8 \%)$ were classified as severely malnourished. Also, most reported altered functional capacity and $41.2 \%$ reported changes in dietary intake. This finding reaffirms the important association of nutritional deficits as a complication of an ileostomy and contributes to emphasize the value of attention and periodic nutritional assessment of the person with ileostomy, besides the institution of measures of planning and dietary education ${ }^{(3,32)}$.

Regarding to energy intake and macronutrients such as carbohydrates, lipids, and proteins, most of the interviewees presented insufficient consumption, except for proteins $(23.5 \%)$. Individuals with a stoma, especially those with ileostomy, tend to decrease total intake and restrict the consumption of some foods due to repercussions on the volume and appearance of feces, issues associated with aesthetics and well-being. This reduction in the nutrient supply, together with the loss in absorption, compromises the maintenance of an adequate nutritional status. The diet with adequate protein intake is important, among other reasons, in the tissue repair after the surgical preparation of a stoma. As for carbohydrates, besides an important energy supply, the consumption of foods rich in white flour and low in fiber helps in reducing the volume and increase the consistency of the feces, improving its appearance. However, lipids are fundamental to this group in the energy supply and in the absorption of liposoluble vitamins ${ }^{(4,33)}$.

The contribution of each of the micronutrients (sodium, potassium, magnesium and vitamin B12) was shown to be inadequate or inadequate in most participants. In a case-control study, serum sodium and magnesium values were reduced when compared to the control group ${ }^{(2)}$. The subjects with ileostomy present great loss of mineral salts and water since the large intestine is the main responsible for absorbing them. As for vitamin B12, its absorption is limited to the ileum, so the absorptive capacity will depend on the resected extent of this segment. Such losses can determine, such as complications, dehydration, and electrolyte disturbances, such as hyponatremia, hypokalemia and hypomagnesemia, in addition to renal failure. On the other hand, deficiency of vitamin B12 may lead to megaloblastic anemia ${ }^{(4,34)}$. In the case of sodium, it is advisable to increase its intake, since the presence of this salt in the intestinal lumen helps to reduce fecal losses. ${ }^{(3,32,34)}$ Also, studies have shown that low urinary sodium was correlated with nutritional depletion ${ }^{(2,35)}$. Considering the above, adequate dietary compensation becomes essential, since these individuals already have the drawback of impairment and often also present a basic disease with high metabolic demand, requiring a higher requirement of such nutrients ${ }^{(4)}$

\section{CONCLUSION}

As sociodemographic characteristics, this study found a population composed predominantly of people over 50 years old, female, married and single, with family income between two and three minimum wages, presenting incomplete elementary school education, that do not exercise paid activity and that do not practice physical activity. The most prevalent comorbidity was diabetes mellitus.

Regarding to ileostomy, the majority considered to be able to perform self-care. The presence of current or previous complications was pointed out by most of the sample, with dermatitis being the most frequent. Oncological diagnosis and surgery time of less than two years also prevailed.

Regarding nutritional status, most of the interviewees presented BMI within the appropriate value. However, more than half of the sample reported significant weight loss after the preparation of the ileostomy. The predominant nutritional diagnosis provided by the ASG was suspected of moderate malnutrition. On the other hand, the contribution of energy, carbohydrates, lipids, sodium, potassium, magnesium and vitamin B12 was insufficient in almost all participants.

Therefore, it is suggested the periodic evaluation of the nutritional status of this population. Thus, it is expected that preventive, therapeutic and maintenance dietary diagnosis and planning may contribute to the nutritional status of the person with the ileostomy.

\section{ACKNOWLEDGEMENTS}

SASPO II professionals are grateful for their willingness to provide information and data about registered individuals and for assisting with data collection schedules. In particular, we thank the nutritionist Nize Renê Ferreira for the shared knowledge and contribution in the delineation of the study, allowing its development and implementation.

\section{Authors' contribution}

Moraes JT: conceptualization, methodology, investigation, writing, revision and edition. Melo AFF and Araújo C: methodology, investigation and writing. Faria RGS and Belo VS: writing, revision and edition. Ferreira NR: conceptualization, methodology, investigation. 


\section{ORCID}

Juliano Teixeira Moraes. Orcid: 0000-0002-1109-962X.

Ana Flávia Faria Melo. Orcid: 0000-0003-1476-8232.

Camila Araújo. Orcid: 0000-0002-3983-0226.
Rafaela das Graças Santiago Faria. Orcid: 0000-0001-95088372.

Nize Renê Ferreira. Orcid: 0000-0002-6470-6358.

Vinícius Silva Belo. Orcid: 0000-0003-0183-1175.

Moraes JT, Melo AFF, Araújo C, Faria RGS, Ferreira NR, Belo VS. Avaliação antropométrica e dietética de pessoas com ileostomias. Arq Gastroenterol. 2019;56(1):34-40

RESUMO - Contexto - Além do manejo adequado das eliminações da estomia, a manutenção da nutrição para a pessoa com ileostomia é um grande desafio. Objetivo - Este trabalho teve como objetivo avaliar o estado nutricional de pessoas com ileostomia. Métodos - Trata-se de um estudo transversal, realizado numa população de 17 pessoas com ileostomia cadastrados no Serviço de Atenção à Saúde da Pessoa Ostomizada de nível II referência para uma região de saúde em Minas Gerais. Foi realizada a avaliação antropométrica que consistiu na coleta do peso, altura e cálculo do índice de massa corporal. Também foi avaliado um recordatório alimentar de 24 horas e o método de avaliação nutricional Avaliação Subjetiva Global. Os dados foram analisados pelo software Dietbox, onde foi estimado os nutrientes ingeridos, e pelo Statistical Package for the Social Sciences versão 22.0. Resultados - Houve predomínio de uma população composta por pessoas com idade superior a 50 anos, do sexo feminino, de estado civil casado e solteiro, com renda familiar entre dois e três salários mínimos, ensino fundamental incompleto e que não exerciam atividade remunerada. O câncer foi dado como principal diagnóstico que originou a estomia e possuíam um tempo de cirurgia menor que dois anos. Quanto ao estado nutricional, a maior parte dos entrevistados apresentaram índice de massa corporal adequada, porém mais da metade referiu perda de peso importante após a confecção da ileostomia. O diagnóstico nutricional predominante, fornecido pela Avaliação Subjetiva Geral foi de "suspeita de desnutrição/desnutrido moderado". Já o aporte de energia, carboidratos, lipídeos, sódio, potássio, magnésio e vitamina B12 foi avaliado como insuficiente na quase totalidade dos participantes. Conclusão - Portanto, sugere-se a avaliação periódica do estado nutricional dessa população. Assim, espera-se que o diagnóstico e planejamento dietético preventivo, terapêutico e de manutenção possam contribuir para a condição nutricional da pessoa com ileostomia.

DESCRITORES - Estado nutricional. Estomia. Serviços de saúde.

\section{REFERENCES}

1. Francone TD. Overview of surgical ostomy for fecal diversion. Walthman (MA): UpToDate; 2017 [Access 2017 August 16]. Available from: http://www.uptodate.com/

2. Ng DH, Pither CA, Wootton SA, Stroud MA. The 'not so short-bowel syndrome': potential health problems in patients with an ileostomy. Colorectal Dis. 2013;15:1154-61.

3. Burch J. Nutrition and the ostomate: input, output and absorption. Br J Community Nurs. 2006;11:349-51

4. Akbulut G. Nutrition in stoma patients: a practical view of dietary therapy. UHOD. 2011;21:61-6.

5. Barbosa MH, Alves PIC, Silva R, Luiz RB, Poggetto MTD, Barichello E. Aspectos nutricionais de estomizados intestinais de um município de minas gerais (Brasil). REAS. 2013;2:77-87.

6. Rocha JJR. Estomas intestinais (ileostomias e colostomias) e anastomoses intestinais. Rev de Medicina de Ribeirão Preto. 2011;44:51-6.

7. Fisberg RM, Marchioni DML, Colucci, ACA. Avaliação do consumo alimentar e da ingestão de nutrientes na prática clínica. Arq Bras Endocrinol Metab. 2009;53:617-24.

8. Brasil. Ministério da Saúde. Secretaria de Assistência a Saúde. Portaria n. 400 de 16 de novembro de 2009. Institui a atenção à saúde da pessoa estomizada. Diário Oficial da União 18 nov. 2009;220(1):41-2.

9. Brasil. Ministério da Saúde. Secretaria de Atenção à Saúde. Departamento de Atenção Básica. Orientações para a coleta e análise de dados antropométricos em serviços de saúde: Norma Técnica do Sistema de Vigilância Alimentar e Nutricional - SISVAN / Ministério da Saúde, Secretaria de Atenção à Saúde, Departamento de Atenção Básica. - Brasília: Ministério da Saúde, 2011.

10. World Health Organization. Physical Status: the use and interpretation of anthropometry. Geneva, Switzerland: WHO, 1995. WHO Technical Report Series, n. 854

11. Detsky AS, McLaughlin JR, Baker JP, Johnston N, Whittaker S, Mendelson RA, et al. What is subjective global assessment of nutritional status? JPEN J Parenter Enteral Nutr. 1987;11:8-13.

12. Barbosa-Silva MC, Barros AJ. Indications and limitations of the use of subjective global assessment in clinical practice: an update. Curr Opin Clin Nutr Metab Care. 2006;9:263-9.
13. Luz MHBA, Andrade DS, Amaral HO, Bezerra SMG, Benício CDAV, Leal ACA. [Characterization of patients submited to intestinal stomas in a public hospital of Teresina-PI, Brazil]. [Article in Portuguese]. Texto \& Contexto - Enferm. 2009;18:140-6.

14. Barbosa MH, Poggetto MTD, Barichello E, Cunha DF, Silva R, Alves PIC, Luiz RB. Aspectos clínicos e epidemiológicos de estomizados intestinais de um município de Minas Gerais. REAS. 2014;3:64-73.

15. Lenza NFB, Sonobe HM, Zago MMF, Buetto LF. Características socioculturais e clínicas de estomizados intestinais e de familiares em um Programa de Ostomizados. Rev Elet Enf. 2013;15:755-62.

16. Miranda SM, Luz MHBA, Sonobe HM, Andrade EML, Moura ECC. Caracterização Sociodemográfica e Clínica de Pessoas com Estomia em Teresina. Estima. 2016;14:29-35.

17. Schwalm MT, Ceretta LB, Farias BM, Bonfanti MDP, Zimmermann KCG, Perfoll R, et al. Perfil das pessoas estomizadas atendidas na clínica escola de enfermagem da Universidade do extremo sul catarinense - UNESC. Revista Iniciação Científica. 2013;11(1).

18. Moraes JT, Assunção RS, Sá FS, Lessa ER, Corrêa LS. Perfil de pessoas estomizadas de uma região de saúde mineira. Enferm. Foco. 2016;7:22-6.

19. Anaraki F, Vafaie M, Behboo R, Maghsoodi N, Esmaeilpour S, Safaee A. Clinical profile and post- operative lifestyle changes in cancer and non-cancer patients with ostomy. Gastroenterol Hepatol Bed Bench. 2012;5:26-30.

20. Melotti FA, Bueno IM, Silveira GV, MEN Silva, Fedosse E. Characterization of patients with ostomy treated at a public municipal and regional reference center. J Coloproctol. 2013;33:70-4.

21. Bonato CR, Marques GQ. Análise do perfil dos usuários com estomia intestinal atendidos em serviço de estomizados de Porto Alegre [monografia]. Vale do Rio dos Sinos - UNISINOS; 2013.

22. Tipos de câncer: Colorretal Rio de Janeiro (RJ): Instituto Nacional de câncer José Alencar Gomes da Silva. [Internet]. [Access 2017 August 15]. Available from: http://www2.inca.gov.br/wps/wcm/connect/tiposdecancer/site/home/colorretal/ definicao 
23. Queiroz CG, Freitas LS, de Medeiros LP, Melo MDM, de Andrade RS, Costa IKF. [Characterization of patients with an ileostomy that are treated on a reference service for patients with an ostomy]. [Article in Portuguese]. Enfermería Global. 2017;46:13-24.

24. Costa JWS, Dantas GF, Souza MBC, Lucena SKP, Costa IKF. Perfil de idosos ileostomizados do Rio Grande do Norte. Congresso internacional de envelhecimento humano; 2015 Set 21-26; Campina Grande, PB. Anais CIEH. 2015:2(1).

25. Karabulut HK, Dinic L, Karadag L. Effects of planned group interactions on the social adaptation of individuals with an intestinal stoma: a quantitative study. J Clin Nurs. 2014; 23:2800-13.

26. Attolini RC, Gallon CW. Qualidade de Vida e Perfil Nutricional de Pacientes com Câncer Colorretal Colostomizados. Rev Bras Coloproct. 2010;30:289-98.

27. Motivos importantes para a prática de atividade física [Internet]. Associação brasileira de ostomizados. [Access 2017 August 15]. Available from: http://www. abraso.org.br/ostomia_esporte.html

28. Neto MAFL, Fernandes DOA, Didoné EL. Epidemiological characterization of ostomized patients attended in referral Center from the city of Maceió, Alagoas, Brazil. J Coloproctol. 2016;36:64-8.
29. Coelho AMS, Oliveira CG de, Bezerra STF, Almeida ANS, Cabra RL, Coelho MMF. [Self care of patients with colostomy, periostomal skin and collecting bag] [Article in Portuguese]. Rev Enferm UFPE. 2015;9:9528-34.

30. Mohil RS, Narayan N, Sreenivas S, Singh N, Bansal A, Singh GJ. Challenges of Managing Emergency Ileostomy: Nutrition - A Neglected Aspect. ISRN Emergency Medicine. 2012;2012. http://dx.doi.org/10.5402/2012/968023.

31. Jang KU, Yu CS, Lim SB, Park IJ, Yoon YS, Kim CW, et al. Factors affecting poor nutritional status after small bowel resection in patients with Crohn disease. Medicine (Baltimore). 2016;95:e4285.

32. Sato PHR. Cuidados nutricionais no paciente com ileostomia. Boletim SBNPE RJ. 2013;15(44)

33. Silva DG, Bezerra ALQ, Siqueira KM, Paranaguá TTB, Barbosa MA. Influência dos hábitos alimentares na reinserção social de um grupo de estomizados. Rev Eletr Enf [Internet]. 2010;12:56-62. Available from: http://dx.doi.org/10.5216/ree v12i1.5246.

34. Villafranca SJA, Abilés J, Moreno G, Goitia BT, Navarro PU, Adán NG. Ostomías de alto débito: detección y abordaje. Nutr Hosp. 2014;30:1391-6.

35. O'Neil M, Teitelbaum DH, Harris MB. Total Body Sodium Depletion and Poor Weight Gain in Children and Young Adults With an Ileostomy: A Case Series. Nutrition in Clinical Practice. 2014;29:397-401. 